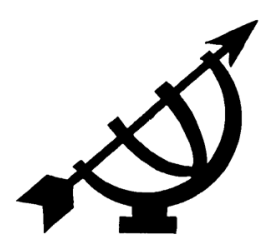

\title{
Technology and religion: Islam, Christianity and materialism
}

\author{
E. Schuurman \\ Emeritus-Professor of Reformational Philosophy \\ Universities of Delft, Eindhoven, Wageningen \\ THE NETHERLANDS \\ E-mail: eschuurman37@hetnet.nl
}

\section{Introduction}

The Western world and the world of Islam share a history, but they also differ greatly. The rise of terrorism has once again made us fully aware of that. In these tense times I would like to consider a question that is rarely raised today, yet which may be very relevant and very revealing: What attitude do these two worlds take toward technology?

When you examine this question in historical perspective you cannot get around the religious background of technology - both in the Islamic world and the West. This theme is very popular today: there is a renewed interest in the vitality of religion around the world and in the arguments regarding its influence on culture (Habermas, 2005), ${ }^{1}$ and - this afternoon ${ }^{2}$ - especially in the historical development of technology.

Let me be clear about what I mean by the term religion. When the media pay attention to religion, they usually treat it as one of many factors or variables in human life, distinct from, say, sport, politics or science. However, if we look carefully at religious communities and various types of societies around the world we can see that religion is not just a typical function or variable among others, but is rather

1 Habermas, J. 2005. Zwischen Naturalismus und Religion.

2 The present essay is the text of Professor Schuurman's valedictory oration delivered in the Auditorium of the University of Wageningen on 20 September 2007. The translation is by Harry van Dyke. 
the root from which the different branches of life sprout and grow and by which they are continually nourished. Religion is of radical and integral importance: it concerns the deepest root of human existence and integrates human life into a coherent whole.

My exploration will consist of the following steps. Firstly, I shall briefly sketch the history of technology in the Islamic world, after which I shall try to clarify the background of the mounting tensions between Islam and the West. We shall review several Islamic ideologists in whose thinking science and technology play a large role. ${ }^{3}$ Islamic critique of technology comes from two sides: from the spiritual, peace-loving Muslims, and from the radical, violent branch of Islam. I shall try to clarify the challenges this poses for the West by looking at the internal tensions in Western culture itself. These turn out to be related especially to technology. The tensions have been present for a long time already, but they have been growing in intensity, ever since the former Christian culture was secularised under the influence of the Enlightenment (also known as the Age of Reason). This intellectual movement, would have nothing to do with religion, yet has an integrating effect of its own nonetheless, and its relation to Christianity became increasingly strained. The Enlightenment represents the religion of the closed material world that is blind to the non-material dimensions of reality. I say this in order to help us gain insight into the nature of the tensions between Islam, Christianity, and Enlightenment-movement in connection with technological development. This will enable us to analyse the problems accurately and give a starting point to lessening our cultural quandaries.

Both the critique of technology provided by Christian philosophy and the critique of technology found in Islam, challenge Western culture to change. A turnabout is needed in the West's dominant cultural paradigm - in the ethical framework within which Western culture is developed. Such a turnabout is crucial, because we are dealing with worldwide problems. It may also lessen tensions with several currents within the Islamic world.

\section{Technology in Islam}

What place does the Islamic world assign to science and technology?

3 I thank my student and fellow philosopher Mohammed Balali from Iran for his critical comments on the text and for his advice about recent Islamic literature on the subject. 
After the death of Mahomet in the year AD 632, early Islam was strongly influenced by the Greek-Hellenistic world. This created an atmosphere conducive to the development of a distinctively Islamic pursuit and promotion of science (Stöcklein, 1990). 4 The pursuit of science was viewed as taking place within the universe created by Allah, a universe that displays order and equilibrium, and thus constitutes an aesthetic unity. The philosophy and science based on this view experienced a long period of blossoming that lasted for more than 500 years, reaching its zenith in the Arab civilisation of the ninth and tenth century and getting further enriched by knowledge imported from Persia, India, and even as far away as China. This was in keeping with the lifelong duty of every Muslim to increase in knowledge. Islamic scholars were already well acquainted with scientific experimentation and technological research. In pursuit of these activities, care for nature was deemed as important as a man's care for his family. It gave a boost to the economic sector such as trade and commerce, which in turn fostered further progress in science and technology. Historians speak of a symbiosis at that time between the Islamic religion and (applied) science, as graphically illustrated by the construction in desert countries of monasteries, mosques, schools and irrigation works.

It is clear that in the Middle Ages the Islamic peoples led the West in science and technology. At the start of the Middle Ages, Islam even mediated between the ancient world and the West. In other words, the West owes a great deal to the Arab world for its scientific development.

Following the eleventh century, however, the pursuit of science in the Arab countries entered a time of stagnation. For a variety of (mostly political and socio-economic) reasons it went into decline. Since then, the Islamic world has increasingly been characterised by traditionalism and isolation, attended by loss of political power and material prosperity. The earlier, positive appreciation of science and technology even turned into a negative one (Al-Hassan, 2001). 5

In later times as well, during the industrial and post-industrial eras, Arab countries contributed little to science and technology, apart from improving the exploration and marketing of crude oil and refin-

4 Stöcklein, A. et al., eds. 1990. Technik und Religion. Düsseldorf.

5 Al-Hassan, A.Y. 2001. Factors behind the decline of Islamic science after the sixteenth century. (In UNESCO. Science and Technology in Islam.) 
ing the weapons technology imported from other countries. There are, however, Islamic scholars today who - as we shall see in a moment - wish to promote modern science and technology in the light of Islam's own past and its original sources (Abu Zayd, 2006). ${ }^{6}$ Their critique is not so much directed at science and technology as such, but rather at the "technological culture" of the West - in other words, at the Western ethics of technology.

\section{The influence of the Enlightenment in the West}

Meanwhile the West, under the influence of its belief in progress (particularly in the age of the Enlightenment), fuelled the prejudicial view that the Islamic world per definition erected more and more roadblocks to arrest science and technology. This was blamed on Islam's contemplative nature and Arab fatalism. That ethos, although at variance with its original attitude, did indeed acquire much influence in the Islamic world. It even reinforces its resistance to Western science and technology. Since the twelfth century, the Islamic world is more oriented to the past than the future.

\section{Reactions inside Islam}

It is important, meanwhile, to distinguish between different reactions in Islam. In the case of more than one Muslim country, those reactions go back to the period of Colonialism. There is first of all the radical, violent, fundamentalist current, which rejects science and technology as well as Westernisation - the ethos of the Enlightenment. There is also the current that accepts both elements from the West. It is mostly found among those who have political and economic power. Understandably the first current turns on them as well. This is the reason why terrorist activities occur just as often in Muslim states as in Western countries.

Then there are, what Huntington calls, the reformists. Others see them as spiritually-minded and peace-loving. They accept the modern developments in science and technology short of the dominant Western ethos. They hold that, as the Islamic world embraces Western science and technology, a thoroughgoing process of rationalisation will have to be accompanied by profound spiritual convictions

6 Abu Zayd, N. 2006. Reformation of Islamic thought: a critical-historical analysis. 
(Hassan, 2007; Soroush, 2004). 7 They often advocate a similar approach to adopting a Western-style democracy (Soroush, 2000).

Ideological differences and growing tensions between these three currents may well cause violent protests against the West to escalate, as well as heighten cultural tensions within the West - which is being populated by Muslims in ever greater numbers. The choices of the smallest group, the fanatical Muslims, pose a violent threat to Western culture. Their urge to destroy casts a sombre shadow over the world.

\section{Enemies of the West}

This destructive urge is explored in a study by Buruma and Margalit (2004). ${ }^{8}$ They use the term occidentalism to refer to the demonisation of the West, as painted by its enemies. The West - led by America - has blanketed the globe with industrialism, capitalism and economic liberalism. The fanatic Muslim regards this "Americanisation" as a machine-civilisation that destroys cultures.

Granted, the spirit of the West is able to develop technology and raise it to ever higher levels for realising ever larger economic successes. But it cannot grasp the higher things of life, because it is woefully lacking in spirituality. It is helpless and hopeless in the very things which, humanly speaking, are important, nay all-important. In the eyes of Muslims, the religion of the West is materialism, and this religion militates against the worship of the Divine spirit.

The hostility that is directed at the West, according to Buruma and Margalit (2004:73), is rooted in this resistance to the "technological culture". Western culture, accordingly, is a spiritless, superficial, materialistic culture of technological presumption, power hunger and greed - a brutish and decadent culture, a culture that deserves to be destroyed. Suicide terrorism has catapulted this hostility against the West to new heights. The suicide bombers, as worshippers of the Divine spirit, send the worshippers of earthly matter to their death with this slogan on their lips: "Death for the sake of Allah is our

7 Hassan, R. 2007. Religion, ethics and violence: developing a new Muslim discourse. (In Goldewijk, B.K., ed. Religion, international relations and development cooperation. Wageningen Academic Publishers.) See also Soroush, A. 2004. Ethics and ethical critiques. www.drsoroush.com 
supreme ambition" (Buruma \& Margalit, 2004:73; cf. also Al-Ansari, 2007). .9 Their war against the West is a holy war.

\section{Islamic terrorism and dialectic tensions in Western culture}

As they analyse Occidentalism, Buruma and Margalit try very hard to understand the enemies of the West. I quote: "Unless we understand why they hate the West so much, we need not nourish the illusion that we can keep them from destroying mankind." (Buruma \& Margalit, 2004:17.) More than once, as I studied their analysis of Western culture and their search for the reasons behind the hatred of our culture, I was reminded of what reformational philosophy has come to see as the dialectical tension within Western culture. It is striking how often these authors look for an explanation in the internal tensions within Western "technological culture" itself. Ever since globalisation has set in, these are tensions that are felt worldwide. Whereas until recently reactions against this culture were confined to the West itself, countermovements are today found around the world. Jihad-terrorism is only the most powerful and dangerous expression of it. It often uses critiques of culture borrowed from Western writers. Popular with many radical Muslims, for example, is the critique of "technological culture" levelled by Martin Heidegger (Abu Zayd, 2006).

\subsection{What is meant by cultural dialectics}

But what exactly is meant by "dialectical tensions" in Western culture? Identifying the dialectic allows us to see what is going on in our culture at a deeper level. It helps us to see the inherent problems, their gravity, but also - seeing their origin and historical development - how they can be, and must be, contained.

The Christian philosopher Herman Dooyeweerd located the origin of the Western dialectic in the imaginary autonomy of man, of the man who is sufficient unto himself, of man without God. Because our culture is closed to the transcendent God, man is thrown back on a this-worldly reality. Western man attempts to realise the idea of selfglorifying autonomy by means of science, and subsequently to confirm it by means of technology. The idea takes hold that modern technology can bring us the perfect man and the perfect world. This

9 Al-Ansari, A.A-H. 2007 The roots of terrorism is the culture of hate. www.memri.org/bin/opener-latest.cgi 
whole development has called up forces that have created tension of gargantuan proportions. The ideal of unprecedented material wellbeing may have been realised in part, but at the same time it is clear that this prosperity has been attained at the price of human freedom, at the expense of the biosphere. With all our prosperity we are standing on the edge of a volcano that is about to erupt. Western culture is a culture that is internally divided. Absolutised freedom is in conflict with the absolutisation of scientific-technological control, and vice versa. It is a tension that shapes the history of our time.

\subsection{The development of dialectical tensions}

Initially, the dialectical tensions - which are at heart religious in nature - were confined to philosophical theories. But under the growing influence of the Enlightenment they have also entered culture under full sail. It is entirely in the spirit of the Enlightenment, after all, not only to understand reality in terms of rationality, but also to shape the world rationally. The Enlightenment project aims at using the instrument of reason to create a society in which human freedom can be enjoyed to the full. The actual situation, however, is that the objective structures which autonomous reason designs and then implements take on a life of their own - independent of man - and as such turn against cultural freedom. That threat is all the more menacing, as the forces to contend with are developing with accelerating dynamics and increasing complexity, so that people can no longer size them up, let alone alter them.

Why is it that mankind's pursuit of mastery and control always seems to win out over that other pole in the cultural dialectic, namely the ideal of freedom? The reason is that the mastery pole utilises the objective powers that manifest themselves in new scientific and technological possibilities such as systems theory, information science, computer technology and genetic manipulation. Economic powers only reinforce that process. However much the critiques are mounting, a turnabout of culture has become almost inconceivable. The cause of that lies especially with economic powers that know no bounds, and a public that is caught in consumerism and repeatedly takes the side of the dominant cultural trend in the hope and belief that even more blessings of science and technology will come their way.

\subsection{The gravity of the current dialectic}

It is essential that we emphasise the increasing seriousness of this historical process. Modern technology and the wholesale application 
of what it can do, is going through unprecedented growth and taking on a despotic character. Its mastery and control of the whole world not only curtails man's freedom but also threatens to deplete natural resources, pollute the environment, and damage nature beyond repair. Of late, increasing attention is being paid to climate change as well. The unbridled scientific-technological dialectic defies natural, ecological, social and energy limits, causing clashes which (owing to the absence of sufficient concrete outlets for the rising tensions) can rapidly escalate into open conflicts (Van der Wal \& Goudzwaard, 2006). 10 The impact of globalising technical and economic development in the Third World often give rise to deep feelings of political impotence, combined with a sense of ongoing economic neglect. It does not take long before people experience this as a direct form of humiliation. Western science and technology, riding the current of globalisation, put enormous pressure on other cultures. The dialectic easily translates into culture wars, ethnic strife, and international standoffs. Thus, political catastrophes may boil over and cultural cataclysms may detonate.

How do Muslim ideologists react to the current cultural situation?

\section{The critique of Islamic ideologists}

One of the most influential Islamic thinkers of the past century - the Egyptian writer Sayyid Qutb (1906-1966) - championed a pure Islamic community as a defence against encroaching Americanism which he interpreted as the empty, idolatrous materialism of the West (Buruma \& Margalit, 2004:36, 116 ff., 124 ff., 131). In the course of his life, the behaviour of the West made him more and more bitter, causing him to be opposed to every form of accommodation. Like all dreams about purity, his ideal of spiritual communion was a fantasy which bore within it the seed of violence and destruction. Qutb became the founder of an Islamic ideology that took on the main ideologies of the West. His rejoinder to Western arrogance was Islamic intolerance (Huntington). His objectives are purity of Islam and destruction of the West. Qutb (1990)11 is a representative of radical Islam which does not flinch from the use of violence in opposing the West, in fact advocates it! In him, the cultural dialectic has become the engine of destruction.

10 Van de Wal, K. \& Goudzwaard, B., eds. 2006. Van grenzen weten: aanzetten tot een nieuw denken over duurzaamheid. Budel.

Qutb, S. 1990. Milestones. Indianapolis: American Trust. 
Fortunately there are also reformists who aim at harmonious coexistence. One of them is Mohammad lqbal (1877-1938), a writer from Pakistan. Iqbal is no occidentalist. He critiques the West from a Muslim perspective, in particular the unbridled development of science and technology, the financial power of capitalism, the inherent forms of economic exploitation, and the secularism attendant upon it. He blames Western influence for detaching people from Allah - thus putting his finger on the worst effect of the Enlightenment - and causing them to serve idols of their own making. Hence he is very critical of Western arrogance, Western imperialism, and public morality in the West. Nevertheless, Iqbal does not take distance from science and technology (Buruma \& Margalit, 2004:122, 152). On the contrary, for his ideas on that score, he takes as his basis the familiar Muslim concept of the unity of Allah. That unity has to be reflected in human society in the form of harmony, expressed in justice, equality, solidarity and care for nature and the environment. Thus, in keeping with the spirit of early Islam, he advocates important reforms in science and technology, hoping in this way to reduce the cultural tensions (Iqbal, 1971; cf. also Foltz et al., 2003). ${ }^{12}$

\section{Points of agreement with Islam}

In the same vein, the Pakistani Muslim Mohammad Abdus Salam (1926-1996), a winner of the Nobel Prize for physics, has made a plea for accepting technology. In a very readable paper he (Salam, 1983)13 states that Allah has placed everything on earth "at the service of" man. Muslim scholars are to acquire insight into the world and thus into Allah's plan. Science must be an integral part of the human community for the purpose of promoting material wellbeing. Accordingly, Salam familiarises himself with the universality of science and technology. Their successes should be a cause of gratitude to Allah and of greater conformity from now on to Allah's will. In order to learn about the proper motives for pursuing science and technology, Salam wants to go back to the early beginnings of Islam, when the torch of scientific and technical development was passed on from generation to generation. For him, therefore, Islam University Press.

13 Salam, M.A, 1983. Science and technology in the Islamic world. (In Buruma, I. \& Margalit, A. Occidentalism. Amsterdam. 
is essential for the correct motivation and ethics of science and technology. In this way, this Muslim scholar has spoken about the relation or interaction between religion and technology in words that are new in the present-day Muslim world, and which are seldom (if ever) heard in the Enlightenment thinking of the Western world.

\section{Christian philosophy and the critique of technology}

That said, reformist Muslims do have a one-sided opinion of Western culture. It is a matter of historical record that the Enlightenment has Christian roots. But this intellectual-spiritual movement, which arose in the eighteenth century, has increasingly distanced itself from Christianity, and has in fact more than once repudiated it. Accordingly, it is not right of Islam to make little or no distinction between the influence of Christianity and that of the Enlightenment, as if the two would necessarily lead to a similar ethics for technology (Buruma \& Margalit, 2004). On the contrary, Christianity, as I have shown, levels a profound criticism at the dialectic tensions inherent in the Enlightenment worldview. In the course of the previous century, both ideals of the Enlightenment - the ideal of human freedom and the ideal of scientific-technological control - have reached a crisis point that may have disastrous consequences for global culture. Dialectical tensions in culture are building up. Radical and violent Islam is offering ever stronger resistance. In other words, Western culture is increasingly being exposed to threats by internal and external forces alike. No one less than Habermas, at heart an Enlightenment philosopher, has recently shown that the "failed Enlightenment" needs religion. Huntington argues that the clash between Islamic and Western civilisations is due to the weakening of Christianity as the central component of the West. The question is pressing: Can a culture that has lost its religious roots survive (Hittinger, 1995)?14 A renewal of Western culture would mean that Westerners return to the religious well-spring of the Christian religion, and that Christianity embraces its cultural calling and actively pursues it. Christianity, on the basis of a powerful conviction, ought to appeal earnestly and emphatically for a turnaround of Western culture. Thankfully, that call is being answered today from all sides. I am thinking here of the effort of the theologian Hans Küng (1997) 15

14 Hittinger, R. 1995. Christopher's Dawson's insights: can a culture survive the loss of Its religious roots? (In Christianity and Western civilization. Ignatius Press.)

Küng, H. 1997. Weltethos für Weltpolitik und Weltwirtschaft. Munich. 
to arrive at a "global ethics" for science and technology. World organisations of churches, too, have published reports in which developments in Western culture are heavily criticised (Opschoor, 2007:247281). 16

There is a lot that is valuable in these calls for change. I do think, however, that they connect the problems and tensions of our culture too much to a disruption of economic relations, and view them too little against the backdrop of the twin ideals of the Enlightenment. Those ideals are in tension with each other. How can that tension be eased? By replacing autonomous freedom with a freedom that answers to values like order, discipline, authority, respect, trust, mutual help, human solidarity - thus a freedom that is linked to responsibility. In addition, a new motivation for science and technology is needed. Dominating power must make way for serviceable power with a view to global justice. The norms and values for technology should no longer be derived from the scientific-technological worldview, which leads ultimately to developments without purpose or direction. This realisation is essential, because it is specifically technology that lies at the basis of many cultural activities. Resorting without question to technological solutions for problems brought about by technology is to pre-program, as it were, new problems and threats. That is why a different view of technology opens up the possibility of reducing or even resolving our cultural problems. The lofty flight of technology needs a transcendental anchor. But how?

What we need to do first of all, is to acknowledge God as the origin of all things, and to recognise man as a responsible creature made in the image of God and commissioned to unfold God's creation with all he has, including science and technology. Such a recognition makes the significance of science and technology subservient to the divine meaning and purpose of history, namely the coming of the kingdom of God (Swearengen, 2007:271).17 In the place of the dominant worldview of the Enlightenment must come an orientation to the unfolding of creation in a disclosure of its potentials, a historical process that began in a garden and will end in a garden-city

16 Opschoor, H. 2007. "Wealth of Nations" or a "Common Future": religion-based responses to insustainability and globalisation. (In Goldewijk, B.K., ed. Religion, international relations and development cooperation. Wageningen Academic Publishers. p. 247-281.)

17 Swearengen, J.C. 2007. Beyond paradise: technology and the kingdom of God. Eugene: Wipf \& Stock. 
(Schuurman, 2005).18 A sustainable and durable society cannot do without religion and spirituality. In short, in its desire for a transformation of "technological culture", Christianity opposes the "religion of matter" as much as reformist Islam does.

For that matter, happily, there are plenty of people outside Christianity and Islam who are keenly aware that Western culture is in need of a fundamental change, a radical shift in direction. A paradigm shift away from "technological culture is necessary".

Any cultural revolution or turnaround will be accompanied by tense discussions, which will ultimately hark back to what people believe and what they consider to be true. The part that religion plays in all this will become unmistakably evident. Religion, or religions, will offer different critiques of culture or technology - as is the case with Christianity and reformist Islam. The challenge will be to come up with a different cultural paradigm that reduces the cultural dialectic and curtails, or even resolves present problems and threats. That will not be easy, because the representatives of the old culture model will not give up on it so quickly: they will hold on to it with a kind of grim stubbornness. I am speaking of economic, political and cultural counterforces. Yet at the same time, the longer current developments continue, the clearer their weakness will become.

\subsection{Cultural turnaround}

Similar turnarounds should address the whole of "technological culture". Owing to looming problems, we are witnessing a growing interest among politicians and economists in cultural alternatives, sustainable development, and socially responsible corporate behaviour. The socio-economic climate is becoming more favourable for drastic change. Recent reports to the government in the Netherlands from the world of business, state that more needs to be done to tackle environmental pollution and climate change (Willems et al., 2006).19 Attention to climate change, rise in sea levels, shifts in climate belts, disruption of ecological systems, loss of biodiversity, new tropical diseases, and so on - all argue for a change in our cultural ethos.

18 Schuurman, E. 2005. The technological world-picture and an ethics of responsibility. Sioux Center: Dordt College Press.

19 Willems, R. et al., 2006. Pleidooi voor een kabinet met een mondiale visie op natuur- en klimaatbehoud. Plea for a cabinet with a global vision for the preservation of nature and the climate. Open Letter to party leaders in the Dutch Parliament, The Hague, Dec. 2006. 
An increasing number of eyes are beginning to see the need for a new cultural paradigm. More and more people are realising that modern society with its patterns of producing, mastering and consuming is inherently, not coincidentally, unsustainable (Van de Wal et al., p. $8 \mathrm{ff}$.).

\subsection{Content of a new cultural paradigm}

But what should the new cultural paradigm look like? What would it be in essence? In the old cultural paradigm, nature is seen as lifeless, and (given that framework), is exploited with unbridled manipulation. Thus, if until recent times nature, man, environment, plants and animals were viewed from a technical perspective - the socalled "machine model" - now the overriding viewpoint in cultural formation will have to be the protection of life. Science, technology and economics should no longer destroy life in all its multiplicity, rich variety of shapes and forms but should, on the contrary, stand in service of it. When that is done, technology and economics will be able to answer better to their intrinsic significance. Proceeding from different religious perspectives, Christianity and Islam, however widely they differ religiously and (I emphasise this), however unbridgeable, these differences will remain, both also have much in common, enabling them to get along in working toward such a cultural turnaround (Rohrmoser, 2006).20 The garden-model suits both Christianity and Islam (Petruccioli, p. 499 ff.; Schuurman, 2005:37 ff.). They seem to concur with this confession: "We love all creation because of the Creator" (Foltz et al., p. 29). Christian and Islamic culture can each in their own way contribute to a globalising culture in which life is not threatened but enriched, and in which greater justice and righteousness is done to ease tensions. For all their great differences, they will together make for greater social cohesion and mutual peace. If, however, Christians lack the power of faith and fail to conclude a moral pact with reformist Islam, then a transformation of culture will not succeed. Then the battle between the competing claims of Enlightenment and radical Islam will intensify and Muslim violence will increase. Then there will be reason enough to remain pessimistic about the future (Bawer, 2006). ${ }^{21}$

Rohrmoser, G. 2006. Islam, die unverstandene Herausforderung. Bietigheim.

21 Bawer, B. 2006. While Europe slept: how radical Islam is destroying the West from within. New York. 


\section{Summarising conclusions}

Technical thinking predominates in industrial society. Virtually everything is viewed in terms of the technical model or - more broadly the machine model. Neither of these models has any room for life as a fundamental and decisive factor. They have guided the application of the power of technology in a tyrannical way. Huge problems have been the result. Today we can see how the "technological culture" threatens life itself to the point of destroying it. A solution to these problems of modern culture is impossible as long as we continue to think and act within the parameters of the technical model. In the new phase of culture and civilisation, however, we shall not say farewell to technology as such but we shall have to put it in the service of life and human society. The reality in which we live our lives must no longer be viewed as an object for technical manipulation but must instead be received in love as a prior given, as a divine creation, as a gift from God. Such an attitude will require respect and awe for the Owner of all things; it will call for receptivity, humility, meekness, wonder, reverence, and prudence. Our appreciation of technology will change completely if the will to power and mastery, is exchanged for respect for all that lives, in all its multi-coloured variety and multiplicity. It will also alter our attitude toward our fellow-man and foster love of the worldwide community of man. The aim of technology should become, not to break down in order to master and control, but to unfold and cause to flourish. For a healthy disclosure of the creation, both Christianity and reformist Islam nurture the perspective of the living and vibrant garden-city, of a culture that takes care of nature and the environment. The preservation of life and well-being is worth more than material prosperity.

\section{Key concepts:}

Christianity

Islam

materialism

religion

technology

\section{Kernbegrippe:}

Christendom

Islam

materialisme

religie

tegnologie 